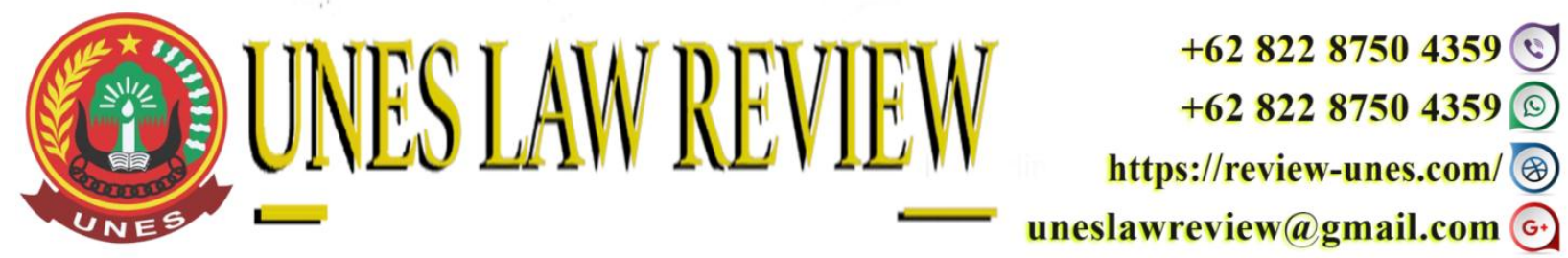

DOI: https://doi.org/10.31933/unesrev.v3i2

Diterima: 19/12/2020, Diperbaiki: 11/01/2021, Diterbitkan: 12/01/2021

\title{
TANGGUNG JAWAB HUKUM NOTARIS TERHADAP AKTA AUTENTIK YANG DIBUAT DIHADAPANNYA (ANALISIS PUTUSAN NOMOR 2022 K/PDT/2013)
}

\author{
Laberqi Pamitama \\ Magister Ilmu Hukum, Universitas Ekasakti, Padang, Indonesia \\ Email: laberqi_pamitama@yahoo.com
}

Corresponding Author: Laberqi

\section{ABSTRACT}

The Notary Deed in Article 1866 and Article 1867 of the Civil Code states that the Notary Deed is written evidence. In carrying out its duties, a Notary must be professional, this is stated in Article 16 letter of the Law on Notary Position. This research is a descriptive analytical study. The approach used in this research is a normative juridical approach. Based on the results of research and discussion, it can be concluded that: First, the form of Notary's legal accountability to the Authentic Deed made before him is the responsibility for the material correctness of the deed, then civil sanctions are imposed for errors that occur in the construction of illegal acts. Actions against the law in this case are active or passive. As a form of notary responsibility in the field of civil law, sanctions in the form of compensation, compensation and interest will be imposed as a result of which the Notary will receive from the lawsuit of the parties if the deed only has evidence as an underhand deed or the deed is null and void by law. Second, the notary can be responsible for the Authentic Deed made before him, it can be from reimbursement of expenses, compensation or interest that can be sued against the Notary based on a legal relationship between the Notary and the parties before the Notary. If there is a party who feels aggrieved as a direct result of a notary deed, then the person concerned can sue the notary publicly. In the case of a lawsuit due to an act against the law, Article 1365 of the Civil Code applies. In this case the Cassation Petitioners were rejected, so the Cassation Petitioners were sentenced to pay court fees at this cassation level.

Kata Kunci: Tanggung Jawab Hukum, Notaris, Akta Autentik

\section{PENDAHULUAN}

Kewenangan Notaris dalam membuat akta autentik lahir melalui Pasal 15 ayat (1) Undang-Undang Nomor 30 Tahun 2004 sebagaimana telah diubah dengan Undang-Undang Nomor 2 Tahun 2014 tentang Perubahan Atas Undang- Undang Nomor 30 Tahun 2004 tentang Jabatan Notaris, yang menyebutkan: 
Notaris berwenang membuat akta autentik mengenai semua perbuatan, perjanjian dan penetapan yang diharuskan oleh peraturan perundang-undangan dan/atau yang dikehendaki oleh yang berkepentingan untuk dinyatakan dalam Akta Autentik (Handri Raharjo, 2009), menjamin kepastian tanggal pembuatan Akta, menyimpan Akta, memberikan gorosse, salinan dan kutipan Akta, semuanya itu sepanjang pembuatan Akta itu tidak juga ditugaskan atau dikecualikan kepada pejabat lain atau orang lain yang ditetapkan oleh undang-undang.

Jabatan Notaris disamping sebagai pejabat umum juga dapat dikatakan sebagai jabatan kepercayaan. Hal tersebut dapat dilihat dari posisi strategis, eksistensi Notaris di tengah-tengah masyarakat, serta kekuatan pembuktian akta autentik yang dibuatnya (Abdul Ghofur Anshori, 2009). Mengingat pentingnya jabatan Notaris baik dilihat dari posisinya ditengah-tengah masyarakat, kewajiban yang diberikan undang-undang maupun kekuatan hukum terhadap aktaakta yang diterbitkannya, mewajibkan Notaris untuk bertanggungjawab melaksanakan profesinya tersebut dengan menjunjung tinggi nilai-nilai, etika, norma-norma hukum, martabat serta keluhuran jabatannya (Arus Akbar Silondae, 2011). Disamping itu, dalam menjalankan jabatanya, Notaris wajib bertindak amanah, jujur, seksama, mandiri, tidak berpihak, dan menjaga kepentingan pihak yang terkait dalam perbuatan hukum.

Meskipun di dalam Undang-undang jabatan Notaris tidak menyebutkan adanya penerapan sanksi pemidanaan tetapi suatu tindakan hukum terhadap pelanggaran yang dilakukan oleh Notaris tersebut mengundang unsur-unsur pemalsuan atas kesengajaan atau kelalaian dalam pembuatan surat atau akta autentik yang keterangan isinya palsu maka setelah dijatuhi sanksi administratif/kode etik profesi jabatan Notaris dan sanksi keperdataan kemudian dapat ditarik dan dikualifikasikan sebagai suatu tindak pidana yang dilakukan oleh Notaris yang menerangkan adanya bukti keterlibatan secara sengaja melakukan kejahatan pemalsuan akta autentik (Habib Adjie, 2008). Dalam bentuk apapun kesalahan tersebut apabila terbukti maka sudah menjadi kewajiban Notaris untuk mempertanggungjawabkan akta yang dibuat oleh atau di hadapannya yang menuai kesalahan tersebut. Dalam Undang Undang Jabatan Notaris hanya ada sanksi perdata dan administasi saja dimana sanksi ini dirasa kurang efektif bagi pihak-pihak yang merasa dirugikan. Akan tetapi Notaris sebagai pejabat umum yang menjalankan profesi dalam memberikan jasa hukum kepada masyarakat perlu mendapatkan perlindungan dan jaminan demi tercapainya kepastian hukum (Abdulkadir Muhammad, 1982).

Contoh notaris yang memiliki masalah dengan penegakan hukum, yang terjadi di Propinsi Sumatera Barat adalah Notaris Elfita Achtar, S.H. Notaris Elfita Achtar, S.H diduga menyimpan Sertifikat untuk diproses dalam pelaksanaan AJB antara PT. Bahwa Penggugat mempunyai sebidang tanah dengan Sertifikat Hak Milik Nomor 377/Nagari Gadut/2005, atas nama Penggugat Elly Suhaimi, seluas 2.112 M2. Penggugat dengan Tergugat I dan II melakukan suatu perjanjian pada tanggal 18 Oktober 2005 Nomor 18 yang dibuat dihadapan Notaris Elfita Achtiar, SH. Dalam perjanjian tersebut Tergugat I dan II akan mendirikan bangunan untuk Penggugat berupa satu unit rumah permanen dengan ukuran 10 x 10 Meter berlantai I. Namun hal ni tidak terjadi sesuai dengan yang diperjanjikan. 


\section{METODE PENELITIAN}

Pendekatan yang digunakan dalam penelitian ini, adalah pendekatan yuridis normatif sebagai pendekatan utama. Yuridis normatif yang berarti hukum dilihat sebagai norma atau das sollen, karena dalam membahas permasalahan penelitian ini menggunakan bahan-bahan hukum (baik hukum yang tertulis maupun hukum yang tidak tertulis atau baik bahan hukum primer maupun bahan hukum sekunder) (Eka Marwahyuni Wira, 2020:250). Permasalahan penelitian ini akan menganalisis putusan Nomor $2022 \mathrm{~K} / \mathrm{Pdt} / 2013)$.

Penelitian ini difokuskan untuk mengkaji dan meneliti materi hukum atau perundangundangan, yang berlaku dan berkompeten untuk digunakan sebagai dasar dalam melakukan pemecahan masalah, sehingga langkah-langkah dalam penelitian ini menggunakan logika yuridis. Pendekatan terhadap hukum yang normatif mengidentifikasikan dan mengkonsepsikan hukum sebagai norma, kaidah, peraturan, undangundangan yang berlaku pada suatu waktu dan tempat tertentu sebagai produk dari suatu kekuasaan negara tertentu yang berdaulat. Dan dalam penelitian ini untuk menguji teori yang telah ada pada suatu situasi konkret (Ronny Hanitijo Sumitro, 1990).

\section{HASIL DAN PEMBAHASAN}

\section{Tanggung Jawab Hukum Notaris Terhadap Akta Autentik yang Dibuat pada Putusan Nomor 2022 K/Pdt/2013.}

Tanggung jawab Notaris sebagai profesi lahir dari adanya kewajiban dan kewenangan yang diberikan kepadanya, kewajiban dan kewenangan tersebut secara sah dan terikat mulai berlaku sejak Notaris mengucapkan sumpah jabatannya sebagai Notaris. Sumpah yang telah diucapkan tersebutlah yang seharusnya mengontrol segala tindakan Notaris dalam menjalankan jabatannya, apalagi ia sebagai pejabat umum. Istilah Pejabat Umum, merupakan terjemahan dari istilah Openbare Amtbtenaren yang terdapat dalam Pasal 1 Peraturan Jabatan Notaris dan Pasal 1868 KUHPerdata. Pasal 1 Peraturan Jabatan Notaris menyebutkan bahwa: "Notaris adalah pejabat umum yang satu-satunya berwenang untuk membuat akta autentik mengenai semua perbuatan, perjanjian dan penetapan yang diharuskan oleh suatu peraturan umum atau oleh yang berkepentingan dikehendaki untuk dinyatakan dalam suatu akta autentik, menjamin kepastian tanggalnya, menyimpan aktanya dan memberikan grosse, salinan dan kutipannya, semua sepanjang pembuatan akta itu oleh suatu peraturan umum tidak juga ditugaskan atau dikecualikan kepada pejabat atau orang lain".

Pasal 1868 KUHPerdata menyebutkan: "Suatu akta autentik ialah suatu akta yang dibuat dalam bentuk yang ditentukan undang-undang oleh atau di hadapan pejabat umum yang berwenang untuk itu di tempat akta itu dibuat". Pasal 1 angka (1) Undang-Undang Jabatan Notaris menyebutkan: "Notaris adalah Pejabat Umum yang berwenang untuk membuat akta autentik dan kewenangan lainnya sebagaimana dimaksud dalam Undang-Undang ini”. Menurut kamus hukum, salah satu arti dari Ambtenaren adalah Pejabat. Demikian dengan Openbare Ambtenaren adalah "pejabat yang mempunyai tugas yang bertalian dengan kepentingan masyarakat, sehingga Openbare Ambtenaren diartikan sebagai Pejabat yang diserahi tugas untuk membuat akta autentik yang melayani kepentingan masyarakat, dan kualifikasi seperti itu diberikan kepada Notaris". 
Berdasarkan ketentuan di atas, Notaris dikualifikasikan sebagai Pejabat umum,tetapi kualifikasi Notaris sebagai Pejabat Umum, tidak hanya untuk Notaris saja, karena sekarang ini seperti Pejabat Pembuat Akta Tanah (PPAT) juga diberi kualifikasi sebagai Pejabat Umum demikian juga Pejabat Lelang. Pemberian kualifikasi sebagai Pejabat umum kepada pejabat lain selain kepada Notaris, bertolak belakang dengan makna dari Pejabat Umum itu sendiri, karena seperti PPAT hanya membuat akta-akta tertentu saja yang berkaitan dengan pertanahan dengan jenis akta yang sudah ditentukan, dan Pejabat Lelang untuk lelang saja. Dengan demikian Notaris melaksakan sebagian tugas negara dalam bidang hukum keperdataan yang sifatnya melayani masyarakat. Hampir sama dengan Pegawai Negeri Sipil (PNS) sifatnya melayani masyarakat artinya negara hadir 54 diberikan kepada Notaris". Berdasarkan ketentuan di atas, Notaris dikualifikasikan sebagai Pejabat ketika masyarakat membutuhkan peran negara yang diwakilkan oleh Notaris. Dan kepada Notaris juga dikualifikasikan sebagai Pejabat Umum yang berwenang untuk membuat akta autentik dan akta merupakan formulasi keinginan atau kehendak (wilsvorming) para pihak yang dituangkan dalam akta Notaris yang dibuat di hadapan atau oleh Notaris, dan kewenangan lainnya sebagaimana dimaksud dalam UUJN.

Terkait dengan kewenangannya tersebut Notaris berkewajiban untuk bertanggung jawab atas perbuatannya/pekerjaannya dalam membuat akta karena masyarakat mempercayakan Notaris tersebut sebagai seseorang yang ahli dalam bidang kenotarisan (Freedy Haris dan Teddy Anggoro, 2010). Dikarenakan besarnya tanggung jawab Notaris ketika menjalankan profesinya mengharuskan Notaris untuk selalu cermat dan hati-hati dalam setiap tindakannya. Namun demikian sebagai manusia biasa, tentunya seorang notaris dalam menjalankan tugas dan jabatannya terkadang tidak luput dari kesalahan baik karena kesengajaan maupun karena kelalaian yang kemudian dapat merugikan pihak lain. Notaris dalam menjalankan jabatannya harus berdasarkan pada ketelitian, kecermatan dan ketepatan. Tiga unsur sifat pribadi harus mendapatkan perhatian khusus yang membentuk karakter didalam menjalankan jabatan adalah: a) Jujur terhadap diri sendiri; b) Baik dan benar; dan c) Profesional.

Salah satu perilaku seorang Notaris dalam menjalankan jabatannya adalah senantiasa bersikap profesional. Menyandang jabatan selaku Notaris harus jujur terhadap diri sendiri yang berlandaskan pada spiritual, moral, mental dan akhlak baik dan benar. Selain mempunyai tingkat intelektual tinggi serta yang mempunyai sifat netral/tidak memihak, independen, mandiri, tidak mengejar materi, menjunjung harkat dan martabat Notaris yang profesional. Perilaku sehari- hari dalam menjalankan jabatannya harus profesional yang mengandung arti: a) Sesuai dengan undang-undang, kode etik, anggaran dasar, anggaran rumah tangga; b) Sesuai dan menguasai teknik pembuatan akta; c) Teliti, jeli dan sikap kehati-hatian harus diperhatikan; d) Tidak terpengaruh dan tidak memihak; e) Merelatir atau membuat sesuai dengan kenyataan yang sebenarnya; f) Tidak menghalalkan segala cara atau memaksakan kehendak; g) Dalam waktu yang cepat dan tepat.

Tugas seorang Notaris adalah membuat suatu akta autentik yang diinginkan oleh para pihak untuk suatu perbuatan hukum tertentu. Tanpa adanya suatu permintaan dari para pihak maka Notaris tidak akan membuatkan suatu akta apapun. Dalam pembuatan suatu akta, Notaris 
pertama sekali haruslah berdasarkan keterangan atau pernyataan dari para pihak yang hadir dihadapan Notaris, selanjutnya Notaris menuangkan keterangan-keterangan/penyataanpernyataan tersebut kedalam suatu akta, tentu saja akta tersebut telah memenuhi ketentuan secara ilmiah, formil dan materiil dalam pembuatan akta autentik. Serta Notaris dalam membuat akta tersebut harus berpijak pada peraturan hukum atau tata cara prosedur pembuatan akta, sehingga Notaris dituntut untuk lebih jeli dan berhati-hati dalam membuat akta. Akta merupakan sebuah kebutuhan bagi masyarakat (para penghadap) dan diharapkan akta tersebut dapat menjadi suatu bukti apabila terjadi suatu sengketa dikemudian hari. Apabila Notaris lalai dan kurang berhatihati dalam membuat akta sehingga mengakibatkan akta tersebut cacat hukum, maka perbuatan Notaris tersebut harus dipertanggungjawabkan. Atas kesalahan notaris tersebut, menyebabkan Notaris telah melakukan perbuatan melawan hukum.

Perbuatan melawan hukum merupakan suatu kumpulan dari prinsip- prinsip hukum yang bertujuan untuk mengontrol atau mengatur perilaku berbahaya (E Utrecht, 1986), untuk memberikan tanggung jawab atas suatu kerugian yang terbit dari interaksi sosial dan untuk menyediakan ganti rugi terhadap korban dengan suatu gugatan yang tepat. Perbuatan harus memenuhi rumusan bahwa perbuatan itu dilarang oleh undang-undang, adanya kerugian yang ditimbulkan dari perbuatan Notaris tersebut serta perbuatan tersebut harus bersifat melawan hukum, baik formil maupun materiil. Mengenai tanggung jawab Notaris selaku pejabat umum, menurut GHS. Lumban Tobing, Notaris harus bertanggung jawab terhadap akta yang dibuatnya, apabila terdapat alasan-alasan sebagai berikut: a) Di dalam hal-hal yang secara tegas ditentukan oleh Peraturan Jabatan Notaris; dan b) Jika suatu akta karena tidak memenuhi syarat-syarat mengenai bentuknya (gebrek in the vorm), dibatalkan di muka pengadilan, atau dianggap hanya berlaku sebagai akta di bawah tangan. Dalam segala hal, dimana menurut ketentuan-ketentuan yang terdapat dalam Pasal 1365 mengenai tanggung jawab dengan unsur kesalahan (kesengajaan dan kelalaian), Pasal 1366 mengenai tanggung jawab dengan unsur kesalahan khususnya kelalaian, dan Pasal 1367 KUHPerdata Terdapat kewajiban untuk membayar ganti kerugian, artinya semua hal-hal tersebut harus mengenai tanggung jawab mutlak (tanpa kesalahan). dilalui proses pembuktian yang seimbang.

\section{Tanggung Jawab Notaris Terhadap Akta Autentik yang Dibuat Dihadapannya}

Notaris merupakan profesi hukum sehingga profesi notaris merupakan suatu profesi yang mulia. Akta yang dibuat oleh notaris dapat menjadi alas hukum atas status harta benda, hak serta kewajiban seseorang. Notaris adalah pejabat umum yang memiliki wewenang untuk membuat akta otentik dan memiliki kewenangan yang lainnya yang dimaksud dalam Undang-Undang jabatan Notaris atau berdasarkan Undang-Undang lainnya. Dalam Pasal 16 Undang-Undang Jabatan Notaris disebutkan bahwa salah satu tugas Notaris adalah bertindak jujur dan amanah dalam menjalankan jabatannya. Namun dalam praktik sudah banyak Notaris yang dipanggil ke pengadilan untuk mempertanggungjawabkan akta otentik yang dibuatnya karena mengandung unsur melawan hukum. 
Tindakan Notaris tersebut sangat tidak sesuai dengan peraturan perundang-undangan dan kode etik notaris dan telah menimbulkan kerugian kepada banyak pihak. Kekeliruan atas akta yang dibuat notaris dapat menyebabkan tercabutnya hak seseorang atau terbebaninya seseorang atas suatu kewajiban, oleh karena itu notaris dalam menjalankan tugas jabatannya harus mematuhi berbagai ketentuan yang telah diatur dalam Undang-Undang Jabatan Notaris. Kewenangan seorang Notaris dalam hal pembuatan akta terdapat dalam Pasal Pasal 1 angka 1 UU Perubahan atas Undang-Undang Jabatan Notaris (UUJN) yaitu membuat akta otentik. Notaris tidak diperbolehkan membuat akta untuk dirinya sendiri, istrinya dan keluarga sedarah. Dalam Undang-Undang Notaris tidak diatur secara pasti bagaimana seorang Notaris itu selaku Pejabat Umum mempertanggungjawabkan secara hukum apabila dia melakukan kesalahan dalam membuat akta yang dibuatnya, hanya dikatakan bahwa seorang Notaris tidak boleh menolak untuk membuat suatu akta yang dimohon dan seorang Notaris tidak boleh membuat akta yang bertentangan dengan hukum. Masih banyak ditemukan bahwa seorang Notaris membuat suratsurat berdasarkan keterangan yang dihadapkan oleh penghadap atau pihak yang menghendaki adanya surat atau akta otentik tersebut tanpa mengetahui kebenaran yang ada dilapangan atau bahkan Notaris keliru dalam mencantumkan keterangan yang diinginkan oleh penghadap.

Pengaturan kewenangan notaris secara jelas telah diatur dalam Pasal 15 UU Perubahan atas Undang-Undang Jabatan Notaris (UUJN) dari kewengan tersebut timbul tanggung jawab notaris sebagai pejabat yang bertugas membuat akta otentik. Notaris dalam menjalankan jabatannya apabila terbukti melakukan pelanggaran, maka sudah seharusnya Notaris bertanggung jawab sesuai dengan perbuatan yang dilakukannya baik tanggung jawab dari segi Hukum Administrasi, Hukum Perdata, yaitu sesuai ketentuan sanksi yang tercantum dalam Pasal 84 dan 85 UU Perubahan atas Undang-Undang Jabatan Notaris (UUJN) dan kode etik, namun didalam Undang-Undang Jabatan Notaris (UUJN) dan UU Perubahan atas Undang-Undang Jabatan Notaris (UUJN) tidak mengatur adanya sanksi pidana (C.S.T Kansil, 1979). Jabatan atau profesi Notaris dalam pembuatan akta merupakan jabatan kepercayaan yang harus dipertanggungjawabkan baik secara hukum maupun secara etika profesi. Sudah diketahui bahwa notaris membuat akta yang bersifat otentik, oleh karena itu Notaris dalam membuat akta haruslah hatihati dan selalu sesuai berdasar pada peraturan yang terlah diberlakukan. Dalam pembuatan akta otentik, Notaris harus bertanggungjawab apabila atas akta yang dibuatnya terdapat kesalahan atau pelanggaran yang disengaja oleh pihak Notaris. Sebaliknya apabila jika unsur kesalahan atau pelanggaran itu terjadi dari para pihak penghadap, maka Notaris bersangkutan tidak dapat diminta pertanggungjawabannya, karena Notaris hanya mencatat apa yang disampaikan oleh para pihak untuk dicatat ke dalam akta.

Pertanggungjawaban notaris dalam pembuatan akta terdapat berbagai segi, yang pertama yaitu Sanksi Hukum Administrasi terhadap Notaris (Hadari Nawawi, 1992) karena kesalahannya yang membuat akta otentik menurut Pasal 85 Undang-Undang Jabatan Notaris (UUJN) yaitu, tanggungjawab dari segi hukum administrasi mengenai sanksi dari Hukum Administrasi dapat berupa teguran lisan, tertulis, pemberhentian sementara, pemberhentian dengan hormat atau pemberhentian dengan tidak hormat. Kedua yaitu tanggungjawab dari segi hukum perdata dalam 
Pasal 84 Undang-Undang Jabatan Notaris (UUJN), bahwa tindakan pelanggaran yang dilakukan oleh Notaris terhadap ketentuan dimaksud dalam beberapa pasal, maka jika salah satu pasal tersebut dilanggar berarti terjadi perbuatan melanggar hukum. Ketiga yaitu tanggungjawab dari segi hukum pidanadalam hal ini akta yang dibuatnya tidak diatur dalam UU Perubahan atas Undang-Undang Jabatan Notaris (UUJN) namun tanggung jawab Notaris secara pidana akan dikenakan apabila Notaris melakukan suatu perbuatan pidana. Dalam hal ini notaris bersangkutan tidak akan dapat diminta pertanggungjawabannya, karena disini Notaris hanya mencatat apa saja yang disampaikan oleh para pihak untuk dituangkan ke dalam akta. Keterangan palsu yang disampaikan oleh para pihak adalah menjadi tanggung jawab para pihak itu sendiri, namun beberapa hal yang dapat dipertanggungjawabkan kepada Notaris adalah apabila adanya penipuan yang bersumber dari Notaris itu sendiri.

Penjatuhan sanksi pidana terhadap Notaris dapat dilakukan sepanjang batasan-batasan tersebut telah dilanggar, artinya disamping untuk memenuhi rumusan pelanggaran tersebut dalam UU Perubahan atas Undang-Undang Jabatan Notaris (UUJN) dan kode etik jabatan Notaris juga harus memenuhi rumusan yang tertera dalam KUHP (H. Salim, 2017). Apabila tindakan pelanggaran atau perbuatan melawan hukum yang dilakukan oleh Notaris memenuhi rumusan suatu tindak pidana, namun jika ternyata berdasarkan UU Perubahan atas UndangUndang Jabatan Notaris (UUJN) suatu pelanggaran. Maka Notaris yang bersangkutan tidak akan dapat dijatuhi hukuman pidana, karena ukuran untuk menilai sebuah akta harus berdasarkan kepada UU Perubahan atas Undang- Undang Jabatan Notaris (UUJN) dan kode etik jabatan Notaris.

Adapun pertanggugjawan dari Notarsi Elfita Actar terhdap akta autentik yang dibuat dihadapannya, berdasarkan putusan Nomor 2022 K/Pdt/2013. Bahwa terhadap gugatan tersebut telah diajukan Eksepsi dan gugatan balik (Rekonvensi) oleh para Tergugat yang pada pokoknya adalah sebagai berikut. Dilihat dari eksepsi:

1. Bahwa pihak Penggugat telah keliru mengajukan gugatannya kepada Para Tergugat ke Kantor Pengadilan Negeri Lubuk Basung, karena kelihatan sekali pihak Penggugat tidak beritikad baik atas perbuatan iktikat baik Para Tergugat selama ini, yaitu pihak Para Tergugat telah melakukan kebaikan kepada Penggugat, dengan melakukan kebaikan yang tidak di perjanjikan dalam surat perjanjian pada tanggal 18 Oktober 2005 Nomor 18 di buat dihadapan Notaris Elfita Achtar, SH. berupa pembuatan Batu Baronjong dengan kawat, panjang lebih kurang $50 \mathrm{~m}$, tinggi lebih kurang 3,5 m, penimbunan dengan tanah serta Dam tanah yang menelan biaya cukup banyak, serta dalam perjanjian Rumah 1 (satu) lantai, sedangkan dibahagian belakangnya 2 (dua) lantai di bangun Para Tergugat, keadaan tanahnya miring dan di buat menjadi dominant oleh Para Tergugat;

2. Bahwa Para Tergugat telah memenuhi perjanjian dengan pihak Penggugat, dengan membuat sebuah rumah permanent yang dibuatkan oleh Para Tergugat melebihi perjanjian tersebut, sehingga Para Tergugat membangun rumah Penggugat cukup sangat bagus; 
3. Bahwa sekarang ini rumah Penggugat di buat oleh Para Tergugat telah mencapai $80 \%$ siap, dengan pemasangan besi-besi baja yang kokoh, beton- beton berkualitas baik, dinding dengan batu bata yang bagus, serta kerangka atap yang baik, telah dipasang atap yang berkualitas tinggi dan hanya yang tinggal lagi berupa plaster dinding, loteng dan daun pintu;

4. Bahwa sebenarnya pada tahun 2009 rumah yang dibuat Para Tergugat tersebut telah siap sempurna, tetapi apa-apa yang diperjanjian oleh pihak Penggugat, yaitu tentang dikeluarkannya izin bangunan oleh pemerintah setempat yang di urus pihak Penggugat tidak kunjung dapat, dan telah di pertanyakan kepada Penggugat, ternyata izin bangunan rumahnya tidak bisa keluar, karena tanah yang tempat bangunan tersebut tidak layak di bangun, disebabkan tanahnya di tepi jurang;

5. Bahwa dengan alasan tidak keluarnya izin bangunan untuk pembangunan rumah tersebut, Para Tergugat berkesimpulan tidak melanjutkan pembangunan rumah tersebut sampai selesai;

6. Bahwa berdasarkan tersebut tanah yang diserahkan Penggugat kepada Para Tergugat berdekatan dengan tanah Penggugat tersebut, tentu tidak bisa pula keluar izin bangunannya dari pemerintahan setempat, maka pada tahun 2009 tersebut Para Tergugat bilang pada Penggugat, untuk mengganti kembali uang Para Tergugat yang telah habis untuk membangun rumah Penggugat dan pengurusan semua sertifikat pihak Penggugat dan Para Tergugat tersebut dan Para Tergugat mengembalikan tanah kepada Penggugat di dalam 4 (empat) buah sertifikat atas nama Tergugat I tersebut;

7. Bahwa Penggugat pada tahun 2009 tersebut, tidak mengindahkan permintaan Para Tergugat, untuk mengembalikan uang untuk pembangunan rumah Penggugat yang telah siap $80 \%$ tersebut kepada Para Tergugat dan Para Tergugat tidak pula menyerahkan tanah 4 (empat) buah sertifikat atas nama Tergugat I tersebut;

8. Bahwa semenjak tahun 2009 tersebut Para Tergugat tidak lagi meneruskan bangunan rumah Penggugat dalam keadaan 80 \% siap tersebut, dan Para Tergugat menunggu, penggantian uang yang telah habis untuk bangunan rumah Penggugat tersebut, ternyata Penggugat tidak memenuhinya, tetapi Penggugat malah menggugat Para Tergugat di Pengadilan Negeri Lubuk Basung ini dengan mempersalahkan Para Tergugat saja;

9. Bahwa sebenarnya Penggugat sejak tahun 2009 tersebut, tetapi berjanji kepada Para Tergugat akan berusaha akan mendapatkan izin bangunan dari pemerintah setempat, ternyata sampai sekarang ini tidak ada izin bangunan rumahnya dan itulah Para Tergugat tidak melanjutkan bangunan rumah Penggugat tersebut;

10. Bahwa Penggugat menerangkan dalam gugatannya 4 (empat) buah sertifikat hak milik Para Tergugat adalah atas nama Tergugat II, sedangkan yang sebenarnya 4 (empat) buah Sertifikat Hak Milik Para Tergugat tersebut adalah atas nama : Tergugat I dan jelas disini pihak Penggugat berbuat melakukan kesalahan yang besar dalam surat gugatannya, karena Penggugat sangat tidak beritikad tidak baik dalam melakukan gugatannya kepada Para Tergugat; 
11. Bahwa sebenarnya Penggugat sejak tahun 2009 tersebut, tetapi berjanji kepada Para Tergugat akan berusaha akan mendapatkan izin bangunan dari pemerintah setempat, ternyata sampai sekarang ini tidak ada izin bangunan rumahnya dan itulah Para Tergugat tidak melanjutkan bangunan rumah Penggugat tersebut;

12. Bahwa Penggugat menerangkan dalam gugatannya 4 (empat) buah sertifikat hak milik Para Tergugat adalah atas nama Tergugat II, sedangkan yang sebenarnya 4 (empat) buah Sertifikat Hak Milik Para Tergugat tersebut adalah atas nama : Tergugat I dan jelas disini pihak Penggugat berbuat melakukan kesalahan yang besar dalam surat gugatannya, karena Penggugat sangat tidak beritikad tidak baik dalam melakukan gugatannya kepada Para Tergugat;

13. Bahwa dalam eksepsi ini pihak Penggugat, telah melakukan kesalahan pula terhadap Para Tergugat, yang seenaknya mempersalahkan Para Tergugat di dalam surat gugatannya, tetapi sebenarnya Para Tergugat tidak ada melakukan kesalahan yang di tudingkan oleh Penggugat kepada Para Tergugat dan dari itu pihak Para Tergugatlah yang sangat merugi dalam masalah perjanjian antara Penggugat dengan Tergugat, yaitu Para Tergugat telah menghabiskan uang untuk membangun rumah Penggugat sebanyak Rp350.000.000,00 (tiga ratus lima puluh juta rupiah) pada tahun 2006, jika di nilai dengan harga uang pada tahun 2012, tentu menjadi lebih kurang sebanyak Rp900.000.000,00 (sembilan ratus juta rupiah), jika uang tersebut di gulirkan dalam perdagangan atau usaha bisnis lainnya tentu pihak Para Tergugat akan mendapatkan keuntungan per harinya paling sedikit Rp1.000.000,00 (satu juta rupiah), maka atas perbuatan Penggugat tersebut pihak Para Tergugat sangat dirugikan Penggugat selama ini, maka Para Tergugat menuntut Penggugat dalam Eksepsi ini mengembalikan uang Para Tergugat sejumlah Rp900.000.000,00 (sembilan ratus juta rupiah) di tambah dengan keuntungan per harinya sejumlah Rp.1.000.000,00 (satu juta rupiah) mulai sejak tahun 2009 sampai putusan perkara ini mempunyai kekuatan hukum pasti.

Sedangkan dalam Rekonvensi bisa dilihat dalam: 1) Bahwa Penggugat Rekonvensi telah menerangkan dalam eksepsi Penggugat Rekonvensi tersebut diatas, tentang kecurangan Tergugat Rekonvensi terhadap Penggugat Rekonvensi selama ini, maka Penggugat Rekonvensi sangat di rugikan oleh Tergugat Rekonvensi, tentang pembiayaan pembangunan sebuah rumah permanent dan pengurusan sertifikat kepunyaan Tergugat Rekonvensi, dengan modal uang Penggugat Rekonvensi sebanyak Rp900.000.000,00 (sembilan ratus juta rupiah) dan jika di gulirkan akan mendapatkan keuntungan dari uang tersebut per harinya paling sedikit sejumlah Rp1.000.000,00 (satu juta rupiah) dan Tergugat Rekonvensi harus memenuhi kerugian Penggugat Rekonvensi tersebut secara materiil dan secara In materiil Penggugat Rekonvensi di rugikan lebih kurang Rp1.000.000.000,00 (satu milyar rupiah) yang harus diganti rugi oleh Tergugat Rekonvensi kepada Penggugat Rekonvensi; dan 2) Bahwa perbuatan Tergugat Rekonvensi melakukan kelalaian tentang keberadaan izin bangunan rumahnya, maka pihak Penggugat Rekonvensi menelan kerugian sebesar Rp900.000.000,00 di tambah kerugian per harinya sejumlah Rp1.000.000,00 adalah merupakan kerugian Materiil Penggugat Rekonvensi dan kerugian 
Immateriil Penggugat Rekonvensi karena kelalaian Tergugat Rekonvensi sejumlah Rp1.000.000.000,00 (satu milyar rupiah).

Bahwa dengan alasan-alasan Penggugat Rekonvensi dalam eksepsi dan dalam pokok perkara, maka Penggugat Rekonvensi mohon pada Bapak, untuk memberikan putusan seperti dibawah ini: 1) Menolak gugatan Penggugat Konvensi/Tergugat Rekonvensi seluruhnya; 2) Mengabulkan gugatan Penggugat Rekonvensi/Tergugat Konvensi seluruhnya; 3) Menyatakan perbuatan Tergugat Rekonvensi/Penggugat Konvensi adalah perbuatan beritikad tidak baik; 4) Menghukum Tergugat Rekonvensi/Penggugat Konvensi untuk mengganti rugi uang kepada Penggugat Rekonvensi/Tergugat Konvensi sejumlah Rp. 900.000.000,00 (sembilan ratus juta rupiah) di tambah ganti kerugian per harinya sejumlah Rp. 1.000.000,00 (satu juta rupiah) dan kerugian Immateriilnya Penggugat Rekonvensi/Tergugat Konvensi sejumlah Rp. 1.000.000.000,00 (satu milyar rupiah), jika ingkar dibantu oleh Alat Negara (Polri); 5) Menghukum Penggugat Rekonvensi mengembalikan berupa Tanah 4 (empat) buah sertifikat atas nama Tergugat Konvensi I kepada Tergugat Rekonvensi/ Penggugat Konvensi jika Tergugat Rekonvensi telah membayar ganti kerugian kepada Penggugat Rekonvensi, berupa sejumlah uang Rp900.000.000,00 ditambah ganti kerugian per harinya sejumlah Rp1.000.000,00 dan kerugian Immateriilnya sejumlah Rp1.000.000.000,00 (satu milyar rupiah); dan 5) Menghukum Tergugat Rekonvensi/Penggugat Konvensi membayar uang perkara ini.

Bahwa terhadap gugatan tersebut Pengadilan Negeri Lubuk Basung telah mengambil putusan, yaitu putusan Nomor 11/Pdt.G/2012/PN.LB.BS. tanggal 20 September 2012 yang amarnya sebagai berikut: Tentang Pokok Perkara: 1) Mengabulkan gugatan Penggugat untuk sebagian; 2) Menyatakan sah Akta Perjanjian Nomor 18 tanggal 18 Oktober 2005 yang dibuat di hadapan Notaris Elfita Achtar, SH.; 3) Menghukum Tergugat I dan Tergugat II untuk menyelesaikan pembangunan rumah sebagaimana Akta Perjanjian Nomor 18 tanggal 18 Oktober 2005 yang dibuat di hadapan Notaris Elfita Achtar, SH; 4) Menghukum Tergugat I dan Tergugat II untuk membayar denda sebesar Rp100.000,00 (seratus ribu rupiah) per hari terhitung sejak tanggal 18 Oktober 2009 sampai Tergugat menyelesaikan kewajibannya; 5) Menolak gugatan Penggugat untuk selebihnya. Menghukum Penggugat dalam Rekonvensi/Tergugat dalam Konvensi untuk membayar biaya perkara yang ditaksir sejumlah Rp1.419.000,00 (satu juta empat ratus sembilan belas ribu rupiah). Menimbang, bahwa dalam tingkat banding atas permohonan Para Tergugat/Para Pembanding putusan Pengadilan Negeri tersebut telah dikuatkan oleh Pengadilan Tinggi Padang dengan putusan Nomor 05/PDT /2013/PT.PDG. tanggal 18 Januari 2013.

Bahwa setelah itu oleh Penggugat/Terbanding yang pada tanggal 20 April 2013 telah diberitahu tentang memori kasasi dari Para Tergugat/Para Pembanding diajukan jawaban memori kasasi yang diterima di Kepaniteraan Pengadilan Negeri Lubuk Basung pada tanggal 15 Mei 2013. Menimbang, bahwa permohonan kasasi a quo beserta alasan-alasannya telah diberitahukan kepada pihak lawan dengan saksama, diajukan dalam tenggang waktu dan dengan cara yang ditentukan dalam undang-undang, maka oleh karena itu permohonan kasasi tersebut formal dapat diterima. Menimbang, bahwa alasan-alasan yang diajukan oleh Pemohon Kasasi/Para Tergugat 
dalam memori kasasinya tersebut pada pokoknya ialah: Bahwa Pengadilan Tinggi Padang dan Pengadilan Negeri Lubuk Basung telah salah dalam menerapkan Hukum dalam perkara ini yaitu dalam mempertimbangkan kedudukan bukti tertulis yang diajukan oleh Tergugat I dan Tergugat II/ Pembanding/Pemohon Kasasi.

Pertimbangan hukum seperti ini adalah keliru; Dengan alasan: Bahwa Terbanding/Tergugat pada saat di persidangan telah memberikan alat bukti berupa Surat Penjelasan Izin Mendirikan Bangunan a.n. Hj. Elly Suhaimi tertanggal 25 Juli 2012 Nomor : 500/323/VII-2012 yang dikeluarkan oleh Camat Tilatang Kamang Kabupaten Agam (bukti bertanda T.7) yang menyatakan bahwa: 1) Lokasi rencana bangunan yang diajukan oleh Sdr. Hj. Elly Suhaimi berada pada posisi tanah dengan kemiringan yang rawan terhadap longsor di Jorong Aro Kandikir Nagari Gadut Kecamatan Tilatang Kamang; 2) Terjadinya longsor disekitar lokasi yang diajukan IMB pada tanggal 17 Maret 2006; 3) Mengingat kondisi diatas pada waktu itu kami menyarankan kepada yang bersangkutan untuk berkonsultasi langsung ke Dinas Pekerjaan Umum Kabupaten Agam, sekaligus menyarankan untuk membawa kelengkapan administrasi pengusursan IMB; dan 4) Sesuai dengan kewenangan yang diberikan kepada Camat, IMB perumahan tidak diterbitkan di Kecamatan tetapi oleh pihak Kabupaten Agam.

Bahwa berdasarkan surat bukti tersebut maka jelaslah Tergugat/Pemohon Kasasi tidak bisa melanjutkan pembangunan rumah tersebut oleh karena keadaan kondisi tempat bangunan tersebut tidak memungkinkan untuk dilanjutkan sehingga IMB tidak bisa dikeluarkan oleh aparat setempat, maka dalam hal ini bukanlah Tergugat yang sengaja tidak memenuhi kewajiban terhadap Penggugat. Bahwa sesuai Pasal 1866 KUHPerdata, alat bukti dalam peradilan perdata adalah:

1) Bukti tertulis; 2) Bukti saksi; 3) Persangkaan; 4) Pengakuan; da 5) Sumpah. Bahwa bukti tertulis yang dimiliki Tergugat/Pembanding/Pemohon Kasasi adalah bukti yang berada di atas bukti saksi yang dimiliki Penggugat Terbanding/ Termohon Kasasi sehingga seharusnya lebih dipertimbangkan oleh Judex Facti; Bahwa berdasarkan pasal tersebut di atas dapat disimpulkan bahwa kekuatan bukti tertulis, berupa bukti penjelasan tentang IMB oleh Camat selaku aparat Pemerintah setempat yang menyatakan bahwa lokasi rencana bangunan yang diajukan oleh Sdr. Hj. Elly Suhaimi (Penggugat) berada pada posisi tanah dengan kemiringan yang rawan terhadap longsor di Jorong Aro Kandikir Nagari Gadut Kecamatan Tilatang Kamang.

Adanya bukti tertulis tersebut diatas, maka dapat dibuktikan bahwa Tergugat/Pembanding/Pemohon Kasasi tidaklah semata-mata telah wanprestasi, sehingga tidak patut dan tidak layak gugatan dalam perkara ini dikabulkan oleh Pengadilan Negeri Lubuk Basung yang juga dikuatkan oleh Pengadilan Tinggi Padang. Bahwa selanjutnya Pengadilan Tinggi Padang dan Pengadilan Negeri Lubuk Basung telah salah dalam menerapkan hukum dalam perkara ini yaitu dalam persidangan di Pengadilan Negeri Lubuk Basung, dimana Tergugat I dan Tergugat II/Pembanding/ Pemohon Kasasi telah meminta waktu untuk menghadirkan saksi-saksi namun Majelis Hakim telah menolak permohonan Tergugat dan 
membatasi untuk menghadirkan saksi-saksi, dalam hal ini menunjukkan adanya keberpihakan Majelis Hakim kepada Penggugat dalam perkara ini.

Meneliti dengan saksama Memori Kasasi tanggal 19 April 2013 dan Kontra Memori Kasasi tanggal 15 Mei 2013 dihubungkan dengan pertimbangan Judex Facti dalam hal ini putusan Pengadilan Negeri Lubuk Basung yang dikuatkan oleh putusan Pengadilan Tinggi Padang, ternyata Judex Facti tidak salah dalam menerapkan hukum dan telah memberi pertimbangan yang cukup untuk mengabulkan gugatan, karena Penggugat dengan bukti-bukti, serta dari keterangan seorang saksi, yaitu Jumardi telah berhasil membuktikan dalil gugatannya, bahwa Tergugat I dan Tergugat II belum menyelesaikan kewajiban mereka untuk menyelesaikan pembangunan rumah Penggugat sebagaimana yang diperjanjikan dalam Akta Perjanjian Nomor 18 tanggal 18 Oktober 2005 yang dibuat dihadapan Notaris Elfita Achtar, SH.

Berdasarkan pertimbangan-pertimbangan tersebut, Pemohon Kasasi harus ditolak dengan perbaikan amar putusan Judex Facti sekedar mengenai denda, harus diganti menjadi uang paksa, karena Tergugat I, Tergugat II dihukum untuk melakukan suatu perbuatan. Berdasarkan pertimbangan diatas, lagi pula ternyata bahwa putusan Judex Facti dalam perkara ini tidak bertentangan dengan hukum dan/atau undang-undang, maka permohonan kasasi yang diajukan oleh Pemohon Kasasi : Hajjah Nurhayati dan kawan tersebut harus ditolak. Menimbang, bahwa oleh karena permohonan kasasi dari Para Pemohon Kasasi ditolak, maka Para Pemohon Kasasi dihukum membayar biaya perkara dalam tingkat kasasi ini. Memperhatikan Undang-Undang Nomor 48 Tahun 2009 tentang Kekuasaan Kehakiman, Undang-Undang Nomor 14 Tahun 1985 tentang Mahkamah Agung sebagaimana yang telah diubah dan ditambah dengan UndangUndang Nomor 5 Tahun 2004 dan perubahan kedua dengan Undang-Undang Nomor 3 Tahun 2009 serta peraturan perundang-undangan lain yang bersangkutan.

\section{KESIMPULAN}

Kesimpulan dalam penelitian ini adalah sebagai berikut ini, yaitu: Bentuk pertanggungjawaban hukum Notaris terhadap Akta Autentik yang dibuat dihadapannya adalah tanggung jawab terhadap kebenaran materiil akta, maka dikenakan sanksi keperdataan terhadap kesalahan yang terjadi dalam konstruksi perbuatan melawan hukum. Perbuatan melawan hukum dalam hal ini dalam sifat aktif maupun pasif. Aktif dalam arti melakukan perbuatan yang menimbulkan kerugian pada pihak lain. Sedangkan pasif, dalam arti tidak melakukan perbuatan yang merupakan keharusan, sehingga pihak lain menderita kerugian. Jadi unsur perbuatan melawan hukum disini yaitu adanya kesalahan dan adanya kerugian yang ditimbulkan. Perbuatan melawan hukum disini diartikan luas, yaitu suatu perbuatan yang tidak saja melanggar undangundang, tetapi juga melanggar kepatutan, kesusilaan, atau hak orang lain dan menimbulkankerugian. Sebagai bentuk pertanggungjawaban Notaris dalam lapangan hukum keperdataan, maka dikenakan sanksi berupa penggantian biaya, ganti rugi dan bunga sebagai akibat yang akan diterima Notaris dari gugatan para penghadap apabila akta bersangkutan hanya mempunyai pembuktian sebagai akta dibawah tangan atau akta batal demi hukum. Notaris dapat bertanggungjawab terhadap Akta Autentik yang dibuat dihadapannya, bisa dari Penggantian 
biaya, ganti rugi atau bunga dapat digugat terhadap Notaris harus dengan mendasarkan pada suatu hubungan hukum antara Notaris dengan para pihak yang menghadap Notaris. Apabila ada pihak yang merasa dirugikan sebagai akibat langsung dari suatu akta notaris, maka yang bersangkutan dapat menuntut secara perdata terhadap notaris.

Dalam hal gugatan karena perbuatan melawan hukum, maka Pasal 1365 KUHPerdata yang berlaku. Pasal 1365 KUHPerdata membuka kemungkinan pengajuan berbagai gugatan yaitu: gugatan ganti rugi, pernyataan sebagai hukum, perintah atau larangan hakim. Terhadap kasus yang penulis angkat, maka dalam pion menimbang, permohonan kasasi dari Para Pemohon Kasasi ditolak, maka Para Pemohon Kasasi dihukum membayar biaya perkara dalam tingkat kasasi ini.

\section{DAFTAR PUSTAKA}

Abdul Ghofur Anshori, (2009), Lembaga Kenotariatan Indonesia(Perspektif Hukum dan Etika), Yogyakarta: UII Press.

Abdulkadir Muhammad, (1982), Hukum Perikatan, Bandung: Alumni.

Arus Akbar Silondae, (2011), Pokok-Pokok Hukum Bisnis, Jakarta: Salemba Empat.

C.S.T Kansil, (1979), Pengantar Ilmu Hukum dan Tata Hukum Indonesia. Balai Pustaka, Jakarta.

Wira, E. (2020). Pelaksanaan Pembinaan Dan Pengawasan Terhadap Pejabat Pembuat Akta Tanah dalam Pendaftaran Hak Atas Tanah di Kota Payakumbuh. UNES Law Review, 2(3), 247-258. https://doi.org/10.31933/unesrev.v2i3.118

E Utrecht, (1986), Pengantar Hukum Administrasi Negara Indonesia, Surabaya: Pustaka Tinta Mas,

Freedy Haris dan Teddy Anggoro, (2010), Hukum Perseroan Terbatas: Kewajiban pemberitahuan Oleh Direksi, Bogor: Ghalia Indonesia.

H. Salim, (2017), Teknik Pembuatan Akta Perjanjian (TPA DUA), Jakarta: PT. Raja Grafindo Persada.

Habib Adjie, (2008), Saksi Perdata dan Administratif Terhadap Notaris Sebagai Pejabat Publik, Bandung: PT. Refika Aditama,.

Hadari Nawawi, (1992), Instrumen Penelitian Bidang Sosial, Yogyakarta: Gajah Mada University Press,.

Handri Raharjo, (2009), Hukum Perjanjian di Indonesia, Yogyakarta: Pustaka Yustisia.

Ronny Hanitijo Sumitro, (1990), Metodologi Penelitian Hukum dan Jurimetri, Jakarta: Ghlmia Indonesia,

Soerjono Soekanto dan Sri Mamudji, (2011), Penelitian Hukum Normatif, Jakarta: Rajawali Pers. 